\title{
Gender and Politics
}

Gill Allwood, Routledge Handbook of Politics and Gender, 2019

All legislation passed in France since the introduction of universal suffrage in 1944 has been made by a parliament comprised of at least $61 \%$ men, and until 2017 , more than $73 \%$ men. Men have decided whether women can have an abortion, whether rape and marital rape are criminal offences, and what clothing women are allowed to wear in public spaces. They have decided what will be taxed and how the budget will be spent. They have made decisions on foreign policy, defence, transport and agriculture, and, until 1945, women were unable to vote and therefore did not even have a say in which men would make these decisions. Gender and politics scholars argue that this matters, although they do not all agree on why it matters. For some, women's presence in sites of decision making matters because they believe that women have different needs and interests (whether this is based on the fact that they are women or that, as women, they have different social experiences), and that these needs and interests are best represented by women politicians. For others, it is less clear that women have a discrete set of needs and interests which are unaffected by class, ethnicity, religion, sexuality and other vectors of inequality. Nevertheless, most agree that there is no justification for the exclusion of women from political decision-making on equal terms with men. Women are now better educated than men (Insee, 2017, p. 114), and are present in the same professions as the men who make up the political elite, even if the glass ceiling prevents them from access to the top echelons of occupational hierarchies. There is no evidence that women lack the competence to occupy high political office or that they are uninterested in doing so. Women are active in local and community politics and in other forms of civic engagement. They may mobilise as feminists, as anti-feminists, or as activists who are motivated by issues other than gender. Women have been active in trade unionism, antiracism and environmentalism, for example. Gender and politics scholars seek to explain why there is a persistent underrepresentation of women in mainstream political institutions, particularly the higher you ascend the pyramid of power. Many are also interested in asking which women are present. They argue that adding white middle-class women from a narrow socio-political and educational background to a male political elite with the same characteristics does not make representative democracy much more representative. Others concentrate on the relation between gender and policy, asking what underlying gendered assumptions influence policymaking and what gendered impact policies have. This chapter reflects these areas of enquiry. It focuses first on women's political participation, from voting behaviour to political office. It then examines the relation between gender and policy, asking how gender issues arrive on the policy agenda, which actors play an important role in promoting and defining them, and what impact the outcomes have on women, men and gender equality.

\section{Political participation - voting behaviour}

French women won the right to vote and to stand for election in 1944, nearly 100 years after men (1848). Women constitute $51.6 \%$ of the population and $52.6 \%$ of the electorate (Haut Conseil à l'Egalité entre les Femmes et les Hommes, 2016, p. 31). How they vote matters to political scientists, and also to political parties and politicians seeking election. In the 2002 presidential election, for example, if only women had voted, Jean-Marie Le Pen would not have made it to the second round. If only men had voted, he would have won the first round (Sineau, 2007, p. 353).

In 1955, two important studies of women's political participation appeared: Mattei Dogan and Jacques Narbonne's (Dogan \& Narbonne, 1955) Les Françaises face à la politique and Maurice Duverger's (Duverger, 1955) La participation des femmes à la vie politique. Dogan and Narbonne took as a starting point the late arrival of women in a political 
system created by men, and asked how successfully they had integrated themselves into it. Did their political behaviour differ from that of men and to what extent? And did these differences vary according to the social and economic status of the women concerned, or were they based purely on sex? They found that women voted less than men and attributed it to their lower levels of political interest and access to information. They also found that nine out of ten women voted like their husbands, claiming that this was because they were subordinate to them and bowed to their superior knowledge. Finally, they found that women voted more to the right than men, although they attributed this to factors other than gender itself, notably age and occupational status.

The second important contribution to the study of women's political participation which appeared in 1955 was Maurice Duverger's report synthesising the results of four national surveys, sponsored by UNESCO and conducted in West Germany, France, Norway and Yugoslavia between 1952 and 1953. In terms of voting turnout and electoral choice, Duverger observed that women's participation did not differ substantially from that of men. He conceded that they abstained more than men, voted to the right and more often for Christian parties, but stated that these differences were very slight. Moreover, they could often be explained by factors other than sex, for example, age.

Until the early 1990s, research by political scientists, Mariette Sineau and Janine Mossuz-Lavau, which formed almost the entire corpus of work on women's political participation in France, showed that women's political behaviour was evolving and would soon 'catch up' with that of men. Later, Mossuz-Lavau (Mossuz-Lavau, 1997) began to argue that women's vote was no longer 'catching up' with that of men, but was developing an autonomy of its own. She divides women's political behaviour since 1945 into three phases, during the course of which women gradually came to vote as much as men, then as much for the left as men, and later, more so. The female electorate is not, however, homogenous. It is differentiated by age, education and occupational status (Sineau, 2007, p. 354), and these divisions have an effect on electoral preference. In the 2007 presidential elections, Sineau found very similar voting preferences between men and women, and very comparable motivations for these choices. Like men, women's choice of candidate was based on concerns about unemployment (39\%), the cost of living (25\%), and social inequalities (23\% women and $22 \%$ men) (Sineau, 2007, p. 356). Sineau identifies a 'gender generation gap' where young men vote less for the left than young women, and older women vote more for the right than older men. However, older women did not vote for Jean-Marie Le Pen. Sineau argues that this is because of the conflict between his politics and their Catholic values. Young women, who are less Catholic, voted for Jean-Marie Le Pen in equal numbers with young men (Sineau, 2007, p. 357). Women's reluctance to vote for the far right is now disappearing under Marine Le Pen's Front National leadership (Mayer, 2013). Nonna Mayer offers three explanations for this. The first relates to occupational segregation. Men are more often blue collar workers, the occupational group with the lowest level of education, income and status, and the most exposed to precariousness and unemployment, where Le Pen votes are more frequent. However, women are over-represented in the growing unskilled service proletariat, which has been hit hard by the economic crisis (Mayer, 2013, p. 173). The second relates to religion. Prior to 2006, religion had no impact on anti-immigrant opinions. Since 2006, however, Catholics have been more anti-immigrant than non-Catholics (Mayer, 2013, p. 174). Thirdly, Marine Le Pen presents a softer image than her father, condemns antiSemitism, and promises more public services, thus appealing to women voters.

\section{Political participation - political office}

Globally, women are under-represented in elected institutions. Only two countries (Rwanda and Bolivia) have attained or exceeded 50\% representation of women (IPU Women in National Parliaments 1 June 2017), and 146 countries out of the 193 listed by the IPU have 
parliaments containing more than $70 \%$ men. The average in Europe is $73.4 \%$ men and in the world $76.6 \%$ men.

The first elections (1945) in which women stood as candidates resulted in a National Assembly with 33 women out of a total of $586(5.6 \%)$. It was assumed that women would gradually acquire confidence and experience, and their numbers would increase. However, 50 years later, in 1995, women still made up only 6.1\% (35/577) of the National Assembly (Allwood \& Wadia, 2000, p. 149). This, combined with concerns about the crisis of representative democracy, led to a search for explanations for the persistently low representation of women, and to a campaign for change.

Early explanations for women's under-representation in sites of decision-making focused on their presumed shortcomings in comparison with men. It was assumed that they were less interested in politics, less knowledgeable, and lacked the skills and experience necessary for political office. Later research challenged these arguments, claiming instead that some electoral systems are less favourable to the renewal of the political elite than others, and that the political parties, which act as gatekeepers to political office, exclude women - and other newcomers - through their candidate selection procedures. It found that institutional culture also acts as an obstacle to women's political participation, as does the public/private split and the construction of the idea of the universal citizen, which hides the exclusion of women (Allwood \& Wadia, 2000, pp. 132-4).

From the late 1970s and throughout the 1980s women politicians, feminists, and alternative left and ecology parties made various attempts to increase women's political representation. They argued that measures had to be introduced which would either remove the obstacles that stood between women and political office, or enable women to overcome them. Initially the demands were for quotas for women within party hierarchies and on candidate lists. However, quotas were widely criticised for running counter to republican universalism and for dividing the nation into categories. By the 1990s, the efforts of campaigners and the opportunism of politicians made the media-friendly notion of 'parity' (numerical equality between men and women) a subject for public debate. In contrast to quotas, parity was supported by a broad spectrum of politicians, all main parties, European organisations, some feminists and intellectuals and a large majority of public opinion (Allwood, 1995).

In the context of concern over the crisis of democracy (low voter turnout, low levels of trust in political institutions), politicians on the left and the right were quick to embrace the idea of parity. The introduction of women into the political elite is claimed by some to be a way of bridging the gap between the people and an increasingly distant elite. Nuanced debates about how this connected to representative democracy were side-lined, and a mainstream politically acceptable version of parity was enshrined in the law in 2000 (see Table 1). This version was brought fully into line with Republican universalism. There could be no suggestion that the state would distinguish between citizens. Instead, it was argued that humanity is universally gendered and that representative bodies should reflect this (Scott, 2005). Sexual difference (fixed and unchanging) was distinguished from other differences which, on the grounds of universalism, continue to be denied public and political relevance (Allwood \& Wadia, 2000, p. 210).

\section{Table 1: the parity laws}

Constitutional reform 8 July 1999. Revision of Articles 3 and 4 of the Constitution of 1958. The following text is added to article 3: 'the law favours equal access for men and women to electoral mandates and elected office'. Article 4 states that 'the parties and political groups contribute to the implementation of this principle.'

The first parity law of 6 June 2000 requires political parties to select an equal number of


women and men in elections in which lists of candidates are presented. Strict alternation of male and female candidates applies in single round elections: European and senatorial. In two-round elections (regional and municipal - in the case of communes with more than 3500 inhabitants), there must be an equal number of women and men candidates in every group of six candidates. Parity is not compulsory in legislative elections. It is encouraged through financial incentives.

Law of 10 July 2000 - a list system is introduced for the indirect election to the Senate in departments electing at least three senators (previously five).

Law of 11 April 2003 - reform of the electoral system for regional and European elections. Introduction of strict alternation of men and women on candidate lists.

Law of 20 July 2003 - reform of the electoral system for senatorial elections. The list system and proportional representation introduced for departments electing at least four senators (rather than three). Single-candidate elections with no legal obligations for parity apply to half of the seats in the Senate.

Law of 31 January 2007 - introduction of strict alternation of women and men on electoral lists for municipal elections (3500+ inhabitants) and introduction of requirement for parity in regional and municipal $(3500+$ inhabitants) executive posts. Increase in the financial penalty applied to parties which do not respect parity in their candidate selection.

Constitutional reform of 23 July 2008. Article 1 of the Constitution is modified to read: 'The law favours the equal access of women and men to electoral mandates and elected office as well as to positions of professional and social responsibility.'

Law of 27 January 2011 - introduces a gradually increasing quota of wome on the executive board of large private companies.

Law of 12 March 2012 - introduction by 2018 of a $40 \%$ quota for the appointment of women to top management positions in public sector organisations.

Law of 22 July 2013 - parity in higher education and research through alternation of women and men in electoral lists and appointments to institutional governance bodies.

Law of 17 May 2013 - reform of the system for electing councillors. Communes of more than 1000 inhabitants (previously 3500+) elect their municipal council by list election, respecting alternation of male and female candidates. General councils are renamed departmental councils, and are now elected by a binominal majority vote (two candidates, one man and one woman, on the same ticket). Departmental executives are also required to respect parity.

Law of 2 August 2013 - reform of senatorial elections. List elections again apply in departments electing at least three senators. These make up $73 \%$ of the seats. Senators are elected indirectly by an electoral college, made up of local representatives. These delegates are now elected on the basis of lists which comprise alternating candidates of each sex.

Law of 14 February 2014 - the law extends rules limiting the number of offices held at any one time. It is no longer legal to combine the following mandates:

national or European parliamentary seat with a local executive office (president or vicepresident of a regional, departmental or intercommunal council, mayor or deputy mayor); parliamentary seat with more than one local mandate (regional, departmental or municipal council);

More than two local mandates/executive functions.

Law of 4 August 2014 - the law for equality between women and men has a section on implementing parity. It doubles the financial penalties for parties which do not respect parity in national elections. It extends the implementation of the equal representation of women and men in public institutions, private companies and sports federations.

Source : (Haut Conseil à l'Egalité entre les Femmes et les Hommes, 2016). 
Many studies have been conducted on the impact of the parity law (Achin \& Lévêque, 2014; Bousquet, Sénac, Badre, \& Berthy, 2017; Haut Conseil à l'Egalité entre les Femmes et les Hommes, 2016; Murray, 2012). They have found that parity has had most success in elected bodies where it has been compulsory and where the electoral system has been most favourable. It has been most effective in municipal council elections in districts of over 3,500 inhabitants, where parity is now almost attained. These elections are run under a proportional representation system with mixed member party lists and strict alternation of male and female candidates. The law of 17 May 2013 has extended this to communes of more than 1000 inhabitants, which previously used a first past the post system, unfavourable to the election of women candidates. Since this change, the proportion of women elected in communes of $1000+$ has increased to 48.2\% (Haut Conseil à l'Egalité entre les Femmes et les Hommes, 2016 , p. 23). No parity measures apply to communes of fewer than 1000 inhabitants, and women remain underrepresented in them.

Candidates in first place on party lists, the chairs of executive bodies (presidents of regional, departmental and intercommunal assemblies and mayors), communes of fewer than 1000 inhabitants, and national assemblies are not constrained by strict parity measures, and have not achieved parity (Haut Conseil à l'Egalité entre les Femmes et les Hommes, 2016, p. 24). As a result of the law of May 2013, female departmental councillors represent half of the assemblies and the executive $(13.8 \%$ in $2011,50.1 \%$ in 2015). But men are $90.1 \%$ of the presidents of departmental councils and $83.3 \%$ of presidents of regional councils (Bousquet et al., 2017, p. 8).

The National Assembly has been resistant. The proportion of women in the National Assembly has never exceeded the current $38.7 \%$ (see Table 2) and did not exceed $20 \%$ until 2012.

Table 2: Percentage of women candidates selected and women elected to the National Assembly:

\begin{tabular}{|l|l|l|}
\hline Year & $\begin{array}{l}\text { Percentage of women } \\
\text { candidates }\end{array}$ & $\begin{array}{l}\text { Percentage of women } \\
\text { elected }\end{array}$ \\
\hline 1958 & 2.3 & 1.3 \\
\hline 1962 & 2.4 & 1.7 \\
\hline 1967 & 2.9 & 1.9 \\
\hline 1968 & 3.3 & 1.7 \\
\hline 1973 & 6.6 & 1.7 \\
\hline 1978 & 16.3 & 4 \\
\hline 1981 & 13.1 & 5.5 \\
\hline 1986 & 25.1 & 5.8 \\
\hline 1988 & 11.9 & 5.6 \\
\hline 1993 & 19.5 & 5.9 \\
\hline 1997 & 23.2 & 10.8 \\
\hline 2002 & 39.3 & 12.1 \\
\hline 2007 & 41.6 & 18.5 \\
\hline 2012 & 40 & 26.9 \\
\hline 2017 & 42.4 & 38.7 \\
\hline
\end{tabular}

Source: (Observatoire des inégalités, 2017a).

The parity laws require parties only to select an equal number of candidates, not to achieve equality of outcome. The smaller parties on the left and far left (les Verts, Lutte Ouvrière, Ligue Communiste Révolutionnaire), followed by the mainstream left (Socialist 
Party and Communist Party), have been more proactive in advancing the goal of parity than the parties of the right and far right. In 2012, only two parties achieved parity in their parliamentary delegation - the Greens, as a result of long-term commitments, and the FN because of their dependence on State funding (Murray, 2013, p. 200). The main parties prefer to pay the fines, despite the increased loss of funding that this entails following reforms introduced in 2007, and first applied in 2012 (Murray, 2013, p. 198). The 2014 law for equality between women and men doubles the financial penalties for parties which do not present equal numbers of women and men (Haut Conseil à l'Egalité entre les Femmes et les Hommes, 2017b).

A record number of women were elected to the National Assembly in June 2017. Of the 577 elected members, 223 are women (up from 155). With 38.7\% women in the lower house, France moves from $64^{\text {th }}$ place to $17^{\text {th }}$ in the world rankings of female parliamentary representation and to $6^{\text {th }}$ place in Europe (Interparliamentary Union, 2017). This is less than the percentage of women candidates selected, showing that they are still more likely to be placed in constituencies which are difficult to win. The $42.4 \%$ women candidates selected is also still short of the 50\% required by the law (Haut Conseil à l'Egalité entre les Femmes et les Hommes, 2017b). The increase in 2017 was due to the doubling of the financial penalties for parties which do not respect parity, the declared commitment to parity by Macron's winning party, and the restrictions on the number of positions that can be held at the same time (cumul des mandats). The practice of holding more than one political office at the same time acts as an obstacle to the renewal of the political elite and to the increase in the proportion of women. The Haut Conseil à l'Egalité entre les Femmes et les Hommes found in its 2013 study that $80 \%$ of members of parliament who held another mandate were men (Haut Conseil à l'Egalité entre les Femmes et les Hommes, 2017b). The law of 22 January 2014 (in force since July 2016) strengthened the limitations introduced in 2000. It is no longer legal to combine:

- National or European parliament and a local executive office (president or vicepresident of regional, departmental or intercommunal council, mayor or deputy mayor);

- Parliament and several local mandates - only one local and one national;

- Several local mandates and local executive functions (Haut Conseil à l'Egalité entre les Femmes et les Hommes, 2016, p. 28).

The parity laws have had a positive effect on the proportion of women in elected office, although this has been very gradual in the case of the parliament. Where the laws have not been stringent, executive posts have also remained in the hands of men. Since 1958, for example, not one of the 15 presidents of the National Assembly has been a woman (Haut Conseil à l'Egalité entre les Femmes et les Hommes, 2017a, p. 1). Within the National Assembly, there is a gendered division of responsibility, with men concentrated in the most powerful parliamentary committees. In the National Assembly in May 2014, women represented $26.1 \%$ of deputies. They were over-represented on the committees for social affairs $(47.9 \%)$ and education and cultural affairs $(40 \%)$, but not on the committees for finance $(13.9 \%)$, foreign affairs $(16.1 \%)$ or defence $(21.1 \%)$ (Achin \& Lévêque, 2014, p. 126).

Women have been more present in government than in parliament in France, rising from $14 \%$ in $1981,27.9 \%$ in 1995 (although this quickly dropped to $12.1 \%$ with Juppé's first reshuffle), 34.4\% in 2007, and 47-50\% throughout Hollande's presidency (2012-17). In 2017, Emmanuel Macron's government has equal numbers of men and women (11 of each), although men hold all of the important portfolios. In France, the government is appointed, rather than being drawn from parliament. Appointing women has therefore been an 
opportunity for male presidents and prime ministers to demonstrate their equality credentials, especially in the early days of new governments when media interest is high.

There are few vocal opponents of the principle that women and men should be equally present in decision making, and the parity laws have made some progress towards achieving this. Parity has also had some symbolic success, as can be seen in the spread of the idea of parity to other areas of public and commercial life, including public administration and corporate boards. However, parity does not ask which women are included and excluded, and it does not challenge the poor representation of particular social groups. The dominant conception of representative democracy in France is one which sees the elected representative as mandated to represent the will of the nation as a whole, rather than to reflect society in all its diversity. The sex, age and ethnicity of the representative have no relevance in public life, and all citizens are equal. While egalitarian in principle, this can, in practice, deny the existence of inequalities, including the exclusion from political life of women and ethnic minorities, amongst others. Elected bodies have acquired more women, but remain exclusive to a social elite, older and white (Achin, 2012, pp. 51-2). In 2017, 2.8\% of deputies in the National Assembly were manual workers or unskilled service sector workers, whereas these categories make up half of the working population (Observatoire des inégalités, 2017b, p. 1). On the rare occasions when ethnic minorities are elected, they are often women. Murray (Murray, 2016) suggests that the appointment of ethnic minority women to government can satisfy gender and ethnic diversity agendas while causing minimal disruption to the white male majority.

By focusing on the insertion of a female elite into political institutions, parity risks missing the question of what difference this would make to all women. We need to ask which women are present in elected bodies and whose interests they represent. Gender inequality must be discussed in the context of other inequalities, including class, ethnicity and religion. Scholars such as Eléonore Lépinard (Lépinard, 2013) and Leah Bassel and Akwugo Emejulu (Bassel \& Emejulu, 2010) have begun to examine the way that these inequalities intersect. Others have focused on groups of women who are particularly marginalised from mainstream political activity such as refugee women (Allwood \& Wadia, 2010) and Muslim women (Joly \& Wadia, 2017), exposing the obstacles that exclude them, but also the diverse forms of activism and civic engagement in which they participate.

\section{Gender and policy}

Gender and politics scholars have been interested in how women's and feminist movements push issues onto the political agenda and frame them in a particular way. They have shown, for example, how feminists fought to place abortion on the political agenda, to have rape defined in law, and to engage policymakers in the struggle against domestic violence (Allwood \& Wadia, 2009). They have studied the relation between activists and feminist actors within state institutions to establish which factors are most likely to produce policy that favours gender equality. Republican universalism has provided a backdrop against which all of this plays out (Bassel \& Emejulu, 2010; Lépinard, 2013; Lépinard \& Mazur, 2009). Positive gender equality outcomes are more likely when there is a 'strategic partnership' (Halsaa, 1998) or 'velvet triangle' (Woodward, 2003), of women in elected office, women's/feminist movements, and women's policy agencies, working together on a specific issue (Mazur, 2002, p. 4). Factors which favour state feminism include the presence in power of left-wing parties when there are links between these parties and the women's movements; coherence within the movement around their demands; and high agenda status within the movement for the issue in question. When these conditions are not present, women's policy agencies with feminist leaders can still intervene effectively. In the absence of effective women's policy agencies and a left-wing government, it is still possible for strong movements to have some impact (Stetson 2001: 295). 
France has a long history of women's policy machinery, which has played a role in much policymaking explicitly concerning women. There has been some kind of government department responsible for women's issues or women's rights since 1974, when Giscard d'Estaing appointed Françoise Giroud as junior minister for women. In 1981, Mitterrand created a ministry for women's rights under Yvette Roudy. The status and title of the department and of the individual responsible for it have changed, as has its funding and potential influence on decision making. The government department has at its service the administrative Service des Droits des Femmes which has a central office in Paris and a network of offices throughout the country. Two parliamentary delegations were created in 1999 in order to advise Parliament on issues relating to women's rights and to ensure the implementation of laws in the area. In addition, there was the Observatoire de la Parité, created in 1995 and responsible for commissioning, undertaking and publishing research on women's status, studying gender inequalities and obstacles to political, social and economic equality, and advising the government. In 2013, it was replaced by the Haut Conseil à l'Egalité entre les femmes et les hommes (HCE).

In 2012, France re-gained a full Ministry for Women's Rights. The minister, Najat Vallaud-Belkacem, introduced a number of policies, including the 2014 law on equality between women and men, which was an attempt to ensure that gender equality cuts through all areas of policy, rather than being seen as a discrete policy issue. Her actions were not without their critics, and in 2013 large numbers protested against same-sex marriage and gender equality education in schools. The ministry was downgraded in 2014 in the second Valls government, when women's rights were moved to Affaires sociales et de la santé, under Marisol Touraine, and Pascale Boistard was appointed head of a secrétariat d'Etat chargé des droits des femmes. In 2017, there is no ministry for women's rights, but a junior minister, Marlène Schiappa, who reports to the Prime Minister.

The study of gender and policy in France has focused to a large extent on the relation between gender and the welfare state, and, in particular, on family, employment and reconciliation (or work-life balance) policy. Studies of the welfare state have demonstrated that it rests on a series of assumptions about the sexual division of labour. Social policy has reinforced the division between the public and the private, associated with production and reproduction, and with men and women. Work on care and on family policy illustrates this. The presumed gender neutrality of public policy is brought into question by scholars such as Jacquot and Mazur (Jacquot \& Mazur, 2010, p. 463). Gender and policy scholars are interested in policy which is obviously gendered, for example, abortion and maternity leave, but also in the gendered effects of ostensibly gender-neutral policy, such as transport and taxation. They ask how issues arrive on the policy agenda, and how these issues are framed as gendered or gender-neutral. They ask what role social movements and other non-state actors, including feminists and women's advocacy networks, play in this process, who is included in and excluded from policy formulation and implementation, and whether the outcomes affect women and men differently. There is a growing interest in implementation, as can be seen in the cross-national comparative research programme, Gender Equality Policy in Practice (GEPP) (Mazur, 2017).

\section{Conclusion}

Public, political and academic debates about gender and politics have been dominated since the early 1990s by the issue of parity. The principle of women's participation in political, economic and social decision making has caught on, and practice has followed in some areas, including the election of local councils. The women who participate in mainstream institutional politics come from a small socio-cultural elite (as do their male colleagues), and parity has not addressed broader questions of democratic representation. Part of the reason for this is the strength of republican universalism, which denies the relevance of 
difference in the public and political sphere. The new generations of multicultural, anti-racist feminisms described by Achin et al. (Achin et al., 2017) could offer a challenge to the forms of state feminism which have dominated debates since the 1990s.

\section{References}

Achin, C. (2012). Au-delà de la parité. Mouvements, 69(1), 49-54. https://doi.org/10.3917/mouv.069.0049

Achin, C., Albenga, V., Andro, A., Jami, I., Ouardi, S., Rennes, J., \& Zappi, S. (2017). Paysage féministe après la bataille. Mouvements, 89(1), 69-77. https://doi.org/10.3917/mouv.089.0069

Achin, C., \& Lévêque, S. (2014). La parité sous contrôle. Égalité des sexes et clôture du champ politique. Actes de la recherche en sciences sociales, 204(4), 118-137. https://doi.org/10.3917/arss.204.0118

Allwood, G. (1995). The Campaign for Parity in Political Institutions in France. In D. Knight \& J. Still (Eds.), Women and Representation (pp. 7-20). Nottingham: WIF Publications.

Allwood, G., \& Wadia, K. (2000). Women and Politics in France. London and New York: Routledge.

Allwood, G., \& Wadia, K. (2009). Gender and Policy in France. Basingstoke: Palgrave Macmillan.

Allwood, G., \& Wadia, K. (2010). Refugee Women in Britain and France. Manchester: Manchester University Press.

Bassel, L., \& Emejulu, A. (2010). Struggles for Institutional Space in France and the United Kingdom: Intersectionality and the Politics of Policy. Politics and Gender, 6(4), 517544. https://doi.org/DOI: 10.1017/S1743923X10000358

Bousquet, D., Sénac, R., Badre, M.-P., \& Berthy, M. (2017). Quel partage du pouvoir entre les femmes et les hommes élu.e.s au niveau local? Paris: Haut Conseil à l'Egalité entre les Femmes et les Hommes.

Dogan, M., \& Narbonne, J. (1955). Les Françaises face à la politique. Paris: Armand Collin.

Duverger, M. (1955). La participation des femmes à la vie politique. Paris: UNESCO.

Halsaa, B. (1998). A strategic partnership for women's policies in Norway. In G. L. Nijeholt, V. Vergas, \& S. Wieringa (Eds.), Women's Movements and Public Policy in Europe, Latin America and the Caribbean (pp. 167-189). New York and London: Garland.

Haut Conseil à l'Egalité entre les Femmes et les Hommes. (2016). Guide de la parité. Paris.

Haut Conseil à l'Egalité entre les Femmes et les Hommes. (2017a). Contraintes renforcées et volontarisme affiché: une progression sans précédent des femmes à l'Assemblée. Retrieved June 19, 2017, from http://www.haut-conseilegalite.gouv.fr/parite/actualites/article/contraintes-renforcees-et

Haut Conseil à l'Egalité entre les Femmes et les Hommes. (2017b). Parité des candidatures aux élections législatives de 2017: une quasi-stagnation en dépit du renforcement des contraintes légales. Paris: Haut Conseil à l'Egalité entre les Femmes et les Hommes. Retrieved from http://www.haut-conseil-egalite.gouv.fr/parite/actualites/article/paritedes-candidatures-aux

Insee. (2017). Femmes et hommes, l'égalité en question. Paris: Institut national de la statistique et des études économiques. Retrieved from www.insee.fr

Interparliamentary Union. (2017). Women in National Parliaments. Situation as of 1 June 2017. Retrieved July 10, 2017, from http://www.ipu.org/wmn-e/classif.htm

Jacquot, S., \& Mazur, A. G. (2010). Politiques publiques et genre. In Dictionnaire des politiques publiques (Vol. 4, pp. 460-469). Paris: Presses de Sciences Po (P.F.N.S.P.).

Joly, D., \& Wadia, K. (2017). Muslim Women and Power: Political and Civic Engagement in 
West European Societies. London: Palgrave Macmillan. https://doi.org/10.1057/978-1137-48062-0

Lépinard, E. (2013). For Women Only? Gender Quotas and Intersectionality in France. Politics and Gender, 9, 276-298.

Lépinard, E., \& Mazur, A. G. (2009). Republican universalism faces the feminist challenge: The continuing struggle for gender equality. In S. Brouard, A. Mazur, \& A. M. Appleton (Eds.), The French Fifth Republic at Fifty: Beyond Stereotypes (pp. 247-266). Basingstoke and New York: Palgrave Macmillan.

Mayer, N. (2013). From Jean-Marie to Marine Le Pen: Electoral Change on the Far Right. Parliamentary Affairs, 66(1), 160-178.

Mazur, A. G. (2002). Theorizing feminist policy. Oxford: Oxford University Press.

Mazur, A. G. (2017). Toward the Systematic Study of Feminist Policy in Practice:An Essential First Step. Journal of Women, Politics \& Policy, 38(1), 64-83. https://doi.org/10.1080/1554477X.2016.1198210

Mossuz-Lavau, J. (1997). L'évolution du vote des femmes. Pouvoirs, 82, 35-44.

Murray, R. (2012). Parity in France: A "Dual Track" Solution to Women's Underrepresentation. West European Politics, 35(2), 343-61.

Murray, R. (2013). Towards Parity Democracy? Gender in the 2012 French Legislative Elections. Parliamentary Affairs, 66(1), 197-212.

Murray, R. (2016). The Political Representation of Ethnic Minority Women in France. Parliamentary Affairs, 69, 586-602. https://doi.org/10.1093/pa/gsv064

Observatoire des inégalités. (2017a). Forte progression de la représentation des femmes à l'Assemblée. Retrieved June 19, 2017, from http://www.inegalites.fr/spip.php?article59

Observatoire des inégalités. (2017b). L'Assemblée ne compte quasiment plus de représentants des milieux populaires. Retrieved June 12, 2017, from http://www.inegalites.fr/spip.php?page=article\&id_article=166\&id_rubrique $=138 \& i d \_g$ roupe $=12 \&$ id $\mathrm{mot}=92$

Scott, J. (2005). Parité: Sexual Equality and the Crisis of French Universalism. Chicago: University of Chicago Press.

Sineau, M. (2007). Effets de genre, effets de génération? Le vote hommes/femmes à l'élection présidentielle 2007. Revue française de science politique, 57(3-4), 353-369. https://doi.org/10.3917/rfsp.573.0353

Woodward, A. (2003). Building velvet triangles: gender and informal governance. In T. Christiansen \& S. Piattoni (Eds.), Informal Governance in the European Union. (pp. 7693). Cheltenham: Edward Elgar. 